\title{
Integration of Sustainability in Engineering and Architectural Studies in Spanish Universities
}

\author{
Leire Guerenabarrena-Cortazar ${ }^{1, *(\mathbb{D}}$, Jon Olaskoaga-Larrauri ${ }^{2}\left(\mathbb{D}\right.$ and Ernesto Cilleruelo-Carrasco ${ }^{2}$ \\ 1 Department of Economics and Management, University of the Basque Country (UPV/EHU), \\ 48008 Bilbao, Spain \\ 2 Industrial Organization and Management Engineering Department, University of the Basque \\ Country (UPV/EHU), 48013 Bilbao, Spain; jon.olaskoaga@ehu.es (J.O.-L.); \\ ernesto.cilleruelo@ehu.eus (E.C.-C.) \\ * Correspondence: leire.guerenabarrena@ehu.eus
}

Citation: Guerenabarrena-Cortazar,

L.; Olaskoaga-Larrauri, J.;

Cilleruelo-Carrasco, E. Integration of Sustainability in Engineering and Architectural Studies in Spanish Universities. Sustainability 2021, 13, 8044. https://doi.org/10.3390/ su13148044

Academic Editor: Barbara Motyl

Received: 25 June 2021

Accepted: 15 July 2021

Published: 19 July 2021

Publisher's Note: MDPI stays neutral with regard to jurisdictional claims in published maps and institutional affiliations.

Copyright: (c) 2021 by the authors. Licensee MDPI, Basel, Switzerland. This article is an open access article distributed under the terms and conditions of the Creative Commons Attribution (CC BY) license (https:// creativecommons.org/licenses/by/ $4.0 /)$.

\begin{abstract}
The recommendations of the UN and other international bodies on the need to transform university curricula to incorporate sustainability values, content and competencies have met with a warm reception from universities all over the world. However, the actual state of the integration of sustainability in higher education is, in general, somewhat more modest than one would expect. This article proposes a method of measuring the extent of sustainability-oriented curricular change in the Spanish University as a whole and applies it to the degrees in engineering and architecture. The method entails a documentary analysis of the teaching guides related to 1050 subjects. The results obtained do not invite optimism: curricular transformation is slow and insufficient and its results are still incomplete.
\end{abstract}

Keywords: sustainability; higher education; Spain; curricular transformation; teaching guides; documentary analysis

\section{Introduction}

If we were to focus exclusively on the time and space that slogans in favour of "sustainable development" occupy in the media, or on the speed with which the term has been incorporated into the language of politics, we would no doubt conclude that society (at least Western society) is finally accepting the responsibility for its part in the process of accelerated destruction of the foundations of its own existence, and that it has finally shouldered the responsibility of implementing the profound transformation which, if it is delayed any longer, will force future generations to bear the punishment for the ignorance of the present.

However, action does not always follow declarations of intent. Even at the individual level, one cannot be sure that what people profess in public is consistent with what they do in the privacy of their own homes. Far be it from us to detract from the importance of social awareness, nearly always a prerequisite for any deep transformation to take place in individual habits or social structures. On the contrary, we would only point out that there is an excess of declarations about sustainable development at both the institutional and individual levels that contrasts with a stark deficit of specific actions.

This imbalance can also be verified in the more specific field of higher education. More and more higher education institutions (HEIs) have publicly declared their ineluctable commitment to sustainable development [1-9] but there is no evidence that they have been equally diligent in transforming their activities to contribute to sustainability. Specifically, according to various analysts [10-15], the HEIs have not been capable of transforming one of their main activities, namely, teaching, which is precisely the source from which their most decisive contribution to sustainability could be expected. 
Indeed, experts have great hopes for the integration of sustainability in higher education curricula [16]. In their opinion, we would be much closer to achieving the fundamental transformation that sustainability demands in our societies if the transformational capacity of HEIs were aimed at instilling more sustainable habits in individuals and training professionals capable of understanding the relationships between their working practice and sustainable development [17-20].

The United Nations (UN) - which has been calling for adaptation of national educational systems for several decades and which has coined a label for this transformationEducation for Sustainable Development (ESD) [21,22]—agrees with this verdict.

However, the prominence that the UN has been granting to the higher education sector [23] is in stark contrast with the absence of profound transformations in national educational systems [10-15,24-29]. The Spanish university is no exception to this general rule. Recent research [30-34] suggest that curricular adaptations in the Spanish universities have been insufficient.

Before judging too harshly the lack of adaptability of the HEIs to any kind of change in their world, it would be as well to remember that the transformation we seek is of an extremely radical nature [22,35]. Simply adding new subjects to the curricula is not enough. Sustainability must transform the curricula across the board [36,37]. Teaching methodologies and assessment systems should be adapted $[38,39]$ and there are even demands that higher education opens the door to the participation of players from outside academia $[25,40]$.

However, the difficulty associated with the goal cannot be used as an excuse. If there really is a (Spanish) university commitment to the integration of sustainability in the curricula, then there should be sufficient mechanisms to assess the degree to which it is being honoured. Among other things, this requires not only setting up objective methods to measure the degree of integration achieved in each university but also objectively determining the progress being made in the university system as a whole. The latter is the aim of this article. It attempts to describe the extent to which the curricula of the engineering and architecture degrees provided by Spanish universities have been adapted to the needs of ESD. The emphasis on engineering and architectural studies is due in part to the close relationship of the authors of this article to these fields of knowledge, but it is also grounded in the assumption that engineering professionals will exert a deeper and more direct influence on sustainability than that from graduates in other fields [41]. After all, they are the engineers and the architects who will be in charge of designing and managing the means, systems and products that our society uses on a daily basis to satisfy the needs of life.

The article consists of four sections, in addition to this introduction. The second section reviews the empirical literature aimed at measuring the adoption of ESD in curricula through objective data from formal documents that describe the content, viewpoint and competencies taught. In the third section, we describe the methods used emphasising those features of the sample selection that guarantee that the results can be extrapolated to all university teaching in the field of engineering and architecture. The fourth section describes the results, ordered according to the research questions. The article ends with a discussion of the results and some conclusions.

\section{Review of the Literature and Substantiation of the Main Contribution of the Article}

The following section provides a brief review of the empirical literature aimed at measuring the adoption of ESD in curricula through objective data from formal documents that describe the content, viewpoint and competencies taught. The first thing that draws our attention is that this body of literature is expanding rapidly at present, so much so that there are several works that focus on the Spanish university $[30,31,33,34,41]$.

Although it is not the intention of this article to conduct a full review, it is worthwhile suggesting a few criteria that could be used in the taxonomy of the research that has been published so far. We can distinguish the following aspects: 
- $\quad$ The institutional scope, i.e., the HEIs under study.

- The documentary reference, i.e., the type of document the content of which is analysed to measure the degree of integration of ESD in the curricula.

- Identification of the semantic terms or categories, the inclusion of which in the documentary references can be considered proof of the integration of ESD in the curricula.

- The observation unit, i.e., the institution or group of institutional activities that is described and analysed.

- The indicators used. In the absence of standard indicators of the degree of integration of the sustainability perspective in the curricula, existing research uses different criteria: sometimes, a mere mention of sustainable development serves to characterise an entire degree course as sustainable. In others, there is a more detailed analysis that considers the number of subjects that have been transformed, the percentage of classroom hours occupied by subjects with sustainable content [18] or the depth with which sustainability competencies are transmitted. The later solution has been adopted, for example, by the EDINSOST group research [30,41,42].

Considering these criteria, literature can be characterised as follows.

- First, there are researches with an international scope [43-45]. These are characterised by the difficulty of establishing a homogeneous documentary reference for research, which is a consequence of the international diversity in the formalisation and communication of the content of the courses. These works usually obtain information from undifferentiated locations on the websites of the HEIs under study. The statistical unit is usually highly aggregated (generally identified with the HEI itself) in this type of research, which consequently lacks sufficient resolution since there is usually a variety of degrees of incorporation of sustainability into the curricula at the same HEI. Lastly, the results are also highly aggregated in this type of work, usually by country or region.

- Other researches analyses several HEIs in a single country [18,31,46-48]. The documentary evidence is usually more homogeneous in this type of research, especially if there are national standards related to the information that universities must publish concerning their teaching approaches, content and methodology. The descriptions and comparisons are usually more rigorous as a result of this homogeneity, but at the expense of the option of making international comparisons. These works tend to compare HEIs in a single country with each other. Sometimes, however, the comparison does not cover all the degrees offered by each HEI but is limited to a few $[41,49,50]$. As a general rule, the results cannot be extrapolated to the country's university system as a whole because the selection of the institutions to be studied fails to ensure that they are representative nationwide.

- A third group of researches aims to describe a single HEI. The Azcárate et al. [34] study at the University of Cádiz (in Spain), the work of Colombo and Alves [51] at an unspecified university in northern Portugal and Bautista-Cerro and Díaz [33] analyse 26 degrees conferred by the National Distance Education University (also in Spain). We can assume that there are no biases derived from the use of nonhomogeneous documentary evidence in these investigations. For this reason, internal comparability between degrees or subjects is reasonably ensured within each HEI. The main drawback to these studies is that, in general, their results cannot be legitimately extrapolated to the entire national system of which they form part, and even less to compare different national systems.

The following conclusions can be drawn from this review of the recent literature on the subject:

(a) In recent years, there has been a proliferation of studies that circumvent the opinions of the agents and try to describe the degree of curriculum renewal by resorting to more objective information. This information comes from official documents that describe university education. 
(b) Notwithstanding the above, researches that meticulously describe the degree of adaptation to ESD in the Spanish university system as a whole have not been performed.

The research reported in this article constitutes another contribution to the body of literature described in this section. It aims to complement the existing literature by providing an analysis that can be extrapolated to the Spanish university system as a whole. Logically, this characteristic is derived from the methodological design of the research described in the next section.

\section{Methods}

\subsection{Objectives}

The main objective of this research is to determine the degree of integration of sustainability in the curricula of engineering and architecture studies in Spanish universities that employ face-to-face teaching.

Certain research questions arise from this general objective:

- Into what percentage of engineering and architecture degrees can it be said that some kind of integration has occurred?

- In what types of university and in which subjects sustainability has been integrated the most?

- Which are the aspects or dimensions of sustainable development that have been incorporated into the curricula the most?

\subsection{Research Approach and Instruments}

This research is empirical in nature and its purpose is descriptive. The article addresses curriculum change for sustainability in engineering and architecture degrees at Spanish universities from the point of view of the design of their subjects. Alternative approaches to the one used here could consist, for example, of assessing the effectiveness of curricular renewal using an approximate measure of the competencies that the students have effectively acquired throughout their academic career $[32,52,53]$. Another approach consists of assessing the incorporation of principles or general rules of action in accordance with the sustainability of the curricula in the strategic plans of the universities or in the degree programs. Degree programs are the documents in which the basic design elements of each degree are displayed, including the competencies that they intend to transmit to the students throughout their training [33,34].

With respect to this last approach, in our opinion, the analysis of the design of the subjects has an important advantage. Unlike strategic plans or degree programs, which are approved by the governing bodies of the universities or by a Curriculum Committee, responsibility for the design of the subjects usually falls on the teachers themselves. Therefore, it seems reasonable to assume that the design of the subjects will be more descriptive of the integration of sustainability in the curricula. Compared with the design of subjects, drawing up strategic plans and degree programs is more probably influenced by the dominant narratives in the sector, the recommendations of the assessment bodies, imitation, the desire to emit an attractive image of the university or a combination of all the above.

In the Spanish university system, the most natural empirical reference for the design of a subject is currently the teaching guide. Teaching guides are one of the novelties that the European Higher Education Area brought to the Spanish university, together with accreditation of university degrees and transformation of teaching-learning methods [54]. A teaching guide is a document that contains the detailed planning of a subject. Its purpose is to inform stakeholders-mainly students - of everything related to the planning and development of the subject. There is no legal provision that imposes content or form requirements on teaching guides. However, most of them roughly follow the indications of the National Agency for Quality Assessment and Accreditation (Agencia Nacional de Evaluación de Calidad y Acreditación-ANECA), according to which the teaching guide includes information about: the name of the subject, the number of credits it carries, whether it is mandatory or optional, its duration and timeframes, its competencies and 
learning results, the training activities and teaching methods, assessment systems, and the content and languages in which it is taught [55].

In practice, teaching guides are usually public and easily accessible by means of the internet. They are of variable length [56] and, in accordance with the findings of our fieldwork, can range from three to twenty pages. They usually consist of the following sections: description and objectives, content, methods, competencies, learning outcomes, assessment systems, a bibliography and other comments.

The approach adopted in the research consisted of identifying objective signs of sustainability in the teaching guides. For these purposes, the teaching guides were subjected to content analysis using a tool specifically designed for the field work. The tool takes the form of a list or catalogue of terms or categories that represent the semantic field of sustainable development. The job of the researchers consisted of searching for these categories in the selected teaching guides.

For these purposes, we worked with the Sustainability Thesaurus drawn up by the "Curriculum and Environment (Ambientalización Curricular) research group of the Universitat de Valencia" (ACUVEG) [57] to determine the categories, a document which, in turn, is inspired by the Declaration of the United Nations Decade of Education for Sustainable Development (2005-2014) [58]. This Thesaurus, which had already been used in other researches [33,59], contains 4 dimensions and 39 categories and was subjected to a process of testing and refinement during analysis of the first 100 teaching guides. Some thesaurus categories were amended, and others were added during this phase in the interests of adapting its terms to the language actually used in the teaching guides. The final form of the catalogue is deployed in Appendix A to this article and respects the fourdimensional structure of the original. The first dimension refers to sustainable development in general, while the remaining three refer to the three habitual areas: the socio-cultural dimension, the environmental dimension and the economic dimension $[60,61]$.

\subsection{Field Work}

The field work consisted of locating, recording, counting and classifying the categories identified in each selected teaching guide.

The categories are not mere search terms but represent a component of the semantic field associated with sustainable development, i.e., they constitute units of meaning in themselves. In practical terms, this means that the search tasks could not be carried out using software programs to search for terms (as in [59]) and that the researchers themselves had to read the teaching guides and identify the cases in which they included the meanings compiled in the catalogue, regardless of whether they used the same signifiers or not. This meant that the presence of a category was sometimes registered even though the teaching guide did not use exactly the same terms as those included in the tool. This was the case with expressions such as "water resource management", "social housing and urban development policies" or "minimum environmental cost".

On other occasions, the presence of terms included in the catalogue was not recorded when said terms were part of the natural content of the subject. For example, terms such as "ecology" were not registered when, due to the nature of the subject, "Ecology and the environment", their presence was considered unavoidable.

To ensure a minimum degree of objectivity in the record, the first 100 teaching guides were read by both the researchers in charge of the field work who would meet at the end of each group of 10 to compare their records and resolve any queries that might have arisen. The criteria of the two researchers converged throughout this first phase until they were practically identical, and from that moment on, each teaching guide was reviewed by a single researcher. Doubtful cases, nevertheless, were still resolved between the two, a precaution which, in its various embodiments, is common in documentary content research $[45,62]$. 


\subsection{Selection and Characterisation of the Sample}

A fundamental difference between this research and previous works is that it is based on a statistically representative sample of all the engineering and architecture studies offered at Spanish universities. With this objective in mind, the first task was to construct a sampling base that exhaustively mirrors the population of the subjects taught in these studies in Spanish universities with face-to-face teaching in the 2019/2020 academic year. A total of 47,495 subjects distributed among all the universities were considered except two private institutions that do not confer engineering or architecture degrees.

A total of 1050 subjects were selected from this sampling base, a number that exceeds the minimum size for a representative sample under simple random sampling conditions (for the estimation of proportions) with a confidence level of $95 \%$ and a margin of error of $3 \%$.

The sample was selected by simple random sampling. During the selection phase, it was found that three private universities do not permit free access to the teaching guides for their subjects. These three universities represent $1.1 \%$ of the total sample base. When random sampling selected one of these subjects, it was replaced by another also chosen at random.

Taking the ownership of the university and the academic year into account, the features of the teaching guides subjected to analysis adequately represent the population as a whole. Nevertheless, optional subjects were somewhat overrepresented in the sample and compulsory subjects underrepresented (Table 1).

Table 1. Characteristics of the population and sample (\%).

\begin{tabular}{cccc}
\hline \multicolumn{2}{c}{ Distribution } & Sample & Population \\
\hline \multirow{2}{*}{ Ownership } & Public University & 85 & 84 \\
& Private University & 15 & 16 \\
\hline Nature of the subject & Mandatory & 66 & 82 \\
& Optional & 31 & 15 \\
& Others & 3 & 3 \\
\hline Course & First year & 18 & 18 \\
& Second year & 20 & 19 \\
& Third year & 28 & 22 \\
& Fourth year & 27 & 21 \\
& Fifth year & 3 & 3 \\
& Others & 4 & 17 \\
\hline
\end{tabular}

\section{Results}

\subsection{Incidence of Curriculum Renewal for the Integration of Sustainability in Engineering and} Architecture Degrees

Most analysts who have studied the integration of EDS in Spanish universities agree that it is still inconsistent, weak or scarce. The results obtained in this research confirm these impressions.

A total of 1596 categories (terms or expressions) related to sustainability were located in the 1050 teaching guides subjected to meticulous analysis, which means a total of 1.52 categories per subject. Indeed, half the subjects in the sample do not mention a single category related to sustainability in their teaching guides. Furthermore, in almost $30 \%$ of the subjects, the categories associated with sustainability appear once or twice at the most in the associated teaching guide (Table 2). 
Table 2. Percentage of subjects that include categories related to sustainability in their teaching guides.

\begin{tabular}{cccccc}
\hline $\begin{array}{c}\text { No. of Mentions of Categories } \\
\text { Related to Sustainability }\end{array}$ & All Subjects & $\begin{array}{c}\text { In Private } \\
\text { Universities }\end{array}$ & $\begin{array}{c}\text { In Public } \\
\text { Universities }\end{array}$ & $\begin{array}{c}\text { In Compulsory } \\
\text { Subjects }\end{array}$ & $\begin{array}{c}\text { In Optional } \\
\text { Subjects }\end{array}$ \\
\hline 0 & 50.0 & 56.1 & 48.9 & 47.4 & 53.7 \\
$1-2$ & 29.7 & 23.9 & 30.7 & 31.3 & 27.4 \\
$3-5$ & 13.1 & 13.5 & 13.1 & 7.7 & 7.7 \\
More than 5 & 7.1 & 6.5 & 7.3 & 6.7 & 7.7 \\
\hline
\end{tabular}

These data must be interpreted in the light of the fact that the teaching guides compile all the information related to the subject in question, including the competencies that it intends to transmit to the students, its content, the study materials, etc. In other words, the absence of categories related to sustainability in the teaching guide of a subject is reliable evidence that any concern about sustainability was absent at the time the teaching guide was designed.

Conversely, teaching guides containing more than two references to the categories related to sustainability are a minority of $20.2 \%$, and only $7.1 \%$ of the teaching guides analysed mention these categories more than five times.

There is not much difference between public and private universities in terms of sustainability integration. Private universities are more likely to offer subjects that completely ignore sustainability ( $56 \%$ versus $49 \%$ ), although this difference is practically offset by subjects in which the attention paid to sustainability is merely token (one or two mentions of categories associated with sustainable development) in which the proportions are $24 \%$ against $31 \%$, respectively. In both categories of university, only one in every five subjects accumulates three or more mentions of sustainable development in their teaching guides.

The results also show that sustainability is better represented in compulsory than in optional subjects, although once again, the magnitude of the differences is not especially significant.

Finally, the results reveal that the presence of categories associated with sustainability is bigger in the higher courses (Table 3). A total of $58 \%$ of the teaching guides of firstyear subjects fail to include a single category related to sustainable development. This percentage is reduced to $46 \%$ by the fourth year. In the fifth course, the incidence drops to $33 \%$, although this figure should be interpreted with caution since most undergraduate courses in Spain are structured in 4 years. The sample only contains 30 fifth-year subjects, an insufficient number to draw reliable conclusions.

Table 3. Percentage of subjects that include categories related to sustainability in their teaching guides (by course).

\begin{tabular}{ccccccc}
\hline $\begin{array}{c}\text { No. of Mentions of Categories } \\
\text { Related to Sustainability }\end{array}$ & All Courses & First & Second & Third & Fourth & Fifth \\
\hline 0 & 49.3 & 58.5 & 52.7 & 45.2 & 46.5 & 33.3 \\
$1-2$ & 30.1 & 28.0 & 28.0 & 32.9 & 29.2 & 40.0 \\
$3-5$ & 13.4 & 10.9 & 13.5 & 15.1 & 13.7 & 10.0 \\
More than 5 & 7.2 & 2.6 & 5.8 & 6.8 & 10.6 & 16.7 \\
\hline
\end{tabular}

\subsection{The Dimensions of Sustainability in Engineering and Architectural Subjects}

Experts in ESD would like the idea that sustainable development is an integral concept because it responds to problems of a systemic nature that affect all aspects of the reality in which we live and work. Ideally, any academic subject that addresses reality from the point of view of sustainable development should simultaneously address [44] the economic, environmental and socio-cultural dimensions $[60,61]$, although, if this is not possible, balanced development of these three dimensions throughout the student's educational experience could be considered to constitute a satisfactory second best.

However, neither of these two conditions exists in engineering and architecture degrees at Spanish universities. Considering the presence of categories related to sustainability in their teaching guides and taking the classification by dimension into account, only 
$2.2 \%$ of the subjects simultaneously address the three dimensions of sustainability. In fact, the most common case is the complete absence of all three, which happens in $52.3 \%$ of the subjects, or that only one is taken into account $(29.2 \%)$.

Moreover, the presence of each dimension in the teaching guides shows significant imbalances. Mentions of the socio-cultural dimension account for $55.1 \%$ of the categories detected in the teaching guides, while at the other extreme, those related to the economic dimension constitute only $2.6 \%$ of the total (Table 4 ).

Table 4. Percentage distribution of mentions among the four dimensions of sustainability.

\begin{tabular}{cccc}
\hline Dimension & All Universities & Public & Private \\
\hline Socio-cultural & 55.1 & 52.3 & 72.8 \\
Environmental & 30.0 & 31.8 & 18.3 \\
Economic & 2.6 & 2.7 & 1.4 \\
Sustainability in general & 12.3 & 13.1 & 7.5 \\
\hline
\end{tabular}

The relatively high number of mentions in the socio-cultural dimension is due in part to the presence of a specific competence which is repeated in 185 subjects out of the total sample of 1050. The following is a literal translation of said competence: "the ability to gather and interpret relevant data (usually within their area of study) to make judgments that include a reflection on important issues of a social, scientific or ethical nature". The ubiquity of this competence in the teaching guides is explained by the fact that it figures in the official list of basic competencies that all students should acquire at university according to the applicable legislation [63].

The imbalance between dimensions affects private universities more than public universities because, in the former, the categories of sustainable development incorporated in the teaching guides are even more highly concentrated in the socio-cultural dimension (Table 4).

Finally, the fact that the aspect that attracts the most attention is the socio-cultural dimension is surprising in view of the technical nature of the degrees under analysis. When the information is broken down by courses (Table 5), it can be seen that this phenomenon is more closely associated with the early than higher courses. This means that the socio-cultural aspects dealt with practically exhaust the attention that the subjects pay to sustainable development in the initial courses. The attention shifts towards environmental issues in the higher courses. The economic dimension of sustainable development is practically ignored at all levels.

Table 5. Percentage distribution of mentions among the four dimensions considered (by course).

\begin{tabular}{ccccccc}
\hline Dimension & $\begin{array}{c}\text { All } \\
\text { Courses }\end{array}$ & First & Second & Third & Fourth & Fifth \\
\hline Socio-cultural & 55.1 & 74.1 & 57.5 & 52.7 & 51.1 & 44.4 \\
Environmental & 30.0 & 12.2 & 28.1 & 31.9 & 34.6 & 40.3 \\
Economic & 2.6 & 0.5 & 2.7 & 2.7 & 3.3 & 2.8 \\
$\begin{array}{c}\text { Sustainability in } \\
\text { general }\end{array}$ & 12.3 & 13.2 & 11.7 & 12.6 & 11 & 12.5 \\
\hline
\end{tabular}

\subsection{Sustainability in Subject Design Components}

The presence of categories that act as signs of the incorporation of sustainability into the curricular design is not distributed homogeneously among all sections of the teaching guides (Table 6). On the contrary, these categories are much more frequent in the section that deals with the competencies developed in each subject. This suggests that research that assesses the introduction of an ESD perspective exclusively by observing the presence of competencies related to sustainable development (for example, [31] probably overvalues it. 
Table 6. Percentage distribution of mentions by dimension and section of the teaching guides.

\begin{tabular}{|c|c|c|c|c|c|}
\hline $\begin{array}{c}\text { Sections of the Teaching } \\
\text { Guide }\end{array}$ & Socio-Cultural & Environmental & $\begin{array}{l}\text { Sustainability in } \\
\text { General }\end{array}$ & Economic & Total \\
\hline Description and objectives & 1.9 & 5.4 & 2.7 & 0.7 & 10.7 \\
\hline Content & 2.4 & 7.0 & 2.3 & 0.8 & 12.6 \\
\hline Methodology & 0.2 & 0.0 & 0.0 & 0.0 & 0.3 \\
\hline Competencies & 39.7 & 14.1 & 5.9 & 0.9 & 60.6 \\
\hline Learning outcomes & 2.7 & 3.1 & 1.2 & 0.3 & 7.4 \\
\hline Assessment system & 0.2 & 0.1 & 0.0 & 0.0 & 0.3 \\
\hline Bibliography & 2.3 & 3.0 & 1.2 & 0.3 & 6.8 \\
\hline Other comments & 0.3 & 0.3 & 0.6 & 0.0 & 1.2 \\
\hline All sections & 49.7 & 33.0 & 13.9 & 3.0 & 100.0 \\
\hline
\end{tabular}

On the contrary, sustainability can hardly be detected in the sections where the assessment system is mentioned, and its presence continues to be scarce in the general headings devoted to presenting the subject and its objectives and in the section dealing with the content.

\section{Discussion and Conclusions}

This article constitutes further evidence of the disconnect between the declarations of commitment to the principles of sustainability - constantly issued from the highest levels of representation of the universities - and the effective transformation of higher education towards a pedagogical model able to transmit the values and skills that its alumni need to work (and live) for (and in) a more sustainable world.

In part, the very nature of the HEIs invites us to suspect that their institutional statements and strategic objectives are so much hot air. University institutions are loosely coupled systems $[64,65]$ which means, in simple terms, that it is unlikely that decisions made by their governing bodies will end up being embodied in organisational action. This feature is even more disturbing when, as in the case of the integration of sustainability, the changes demanded are transversal and setting up a new organisational unit (for example, a staff cabinet in charge of dealing with the issue of sustainability) is not enough and disrupting the comfortable routine of every single member of the organisation eventually becomes inevitable.

These same arguments are used to justify the fact that monitoring and assessment of curricular transformation towards ESD are carried out at the level of the design of each subject.

A brief review of the results obtained by this research will tell us that transformation of the curricula in university engineering and architectural studies is incomplete and insufficient in several ways:

(a) In the first place, because it impacts an insufficient number of subjects. According to the data set forth above, more than half the teaching guides in engineering and architectural studies fail to incorporate a single reference that suggests that they have adopted an ESD approach.

(b) In most of the remaining subjects, the changes have been mere tokens (the categories associated with sustainable development fail to appear on more than two occasions in $30 \%$ of the teaching guides), and in some cases, they appear to be mere compromise decisions. This suspicion is based on the high number of cases in which the teaching guides literally copy one of the competencies included in Royal Decree 1393/2007 on the organisation of official university education.

(c) Furthermore, the categories linked to sustainability that have been identified are concentrated in the socio-cultural sphere, which seems incompatible with authentic integration of sustainability in studies of an eminently technical nature such as engineering and architecture. 
(d) Finally, the paucity of the transformations is also evidenced by the fact that, when drafting the teaching guides, the language of sustainability has permeated the wording of the competencies relatively more, while the methodology, the content or the results of the learning process have been affected to a far lesser degree. This leads us to conclude that, in a large number of subjects, the competencies of the subjects have been adapted, but conversely, neither their contents nor the results of the learning process have been changed.

These weaknesses contrast, as we have already noted, with the decidedly transversal nature that the doctrine intends to stamp on ESD.

From the evidence deployed in this article, the most immediate conclusion would be that the introduction of ESD in engineering and architecture studies at Spanish universities must be fostered more effectively. Determining the causes of the limited progress that has been made so far and suggesting solutions is by far a harder task. An easy and frequent option is to blame the disinterest of the teachers. However, previous surveys [66] conclude that the majority of university teachers in Spain are in favour of the incorporation of sustainability into their subjects. With respect to the responsibility of the university institutions themselves, we have already referred to their loosely coupled nature and the limited efficacy with which their management bodies influence teaching. In the case of the Spanish university, the adaptation of the university curricula to the requirements of the European Higher Education Area must be added. This reform, which is still recent, entailed a significant effort by Spanish university teachers, who have accumulated reasons to oppose new major transformations and who, in all probability, have developed skills to simulate their adaptation to formal requirements without essentially modifying the practice of their work.

It seems, therefore, that any intention to impose transformations in the direction of ESD by way of general, scheduled reform in the Spanish university system as a whole would end up as a simulation exercise. It would probably end with the application of a new "academically correct" language in the description of the subjects and university studies but disconnected from the real content that is actually taught.

In our opinion, communication and teacher training policies would be more effective to make the potential provided by ESD visible and to encourage teachers to experiment with it [67]. Moreover, ESD will probably end up being understood as an interesting differentiating factor for certain universities. If this is the case, it will be student demand that will eventually force the pace and depth of the transformation towards more sustainable curricula.

On a final note, measuring the degree of curricular transformation is a complex task, and this research addresses it in a necessarily limited and imperfect way. Its method, based on documental analysis, means that it depends on the fidelity with which the teaching guides represent the reality of the teaching at university, and this condition, as suggested above, is not always met. The only solution to this problem would be to combine the different approaches to accumulate evidence from the opinions of agents (mainly teachers and students), from objective examination of the sustainability competencies acquired by students, or even from the experience of the companies that employ university graduates.

Author Contributions: Conceptualization, L.G.-C., J.O.-L. and E.C.-C.; methodology, L.G.-C., J.O.-L. and E.C.-C.; validation, L.G.-C., J.O.-L. and E.C.-C.; formal analysis, L.G.-C., J.O.-L. and E.C.-C.; investigation, L.G.-C., J.O.-L. and E.C.-C.; methodology, L.G.-C., J.O.-L. and E.C.-C.; writing-original draft preparation, L.G.-C., J.O.-L. and E.C.-C.; writing-review and editing, L.G.-C., J.O.-L. and E.C.-C. All authors have read and agreed to the published version of the manuscript.

Funding: This research received no external funding.

Institutional Review Board Statement: Not applicable.

Informed Consent Statement: Not applicable.

Data Availability Statement: Not applicable.

Conflicts of Interest: The authors declare no conflict of interest. 


\section{Appendix A. Instrument for Analysis of the Content of the Teaching Guides}

List of dimensions and categories of the tool used in the analysis.

\begin{tabular}{ll}
\hline Dimensions & Categories and associated terms \\
\hline Sustainability & Sustainability: sustainable development, unsustainable, sustainable, etc. \\
\hline & Universal accessibility \\
& Well-being and quality of life: common good, improving quality of life and helping well-being \\
& Demographics: changes, circumstances, etc. \\
& Fundamental rightsHuman rights \\
& Universal rights \\
& Ethics: ethical principles, ethical behaviour, ethical values, etc. \\
& Governance: democracy, transparency, freedom of opinion, citizen participation, etc. \\
& Equal opportunities (non-discrimination): equity, plurality, equal rights, etc. \\
& Equality between men and women: gender equality, non-sexist language, non-discrimination based on \\
& sex, etc. \\
& Social impact: human influence and intervention in society, understanding of social responsibilities derived \\
& from human activity, etc. \\
& Social justice: social values, respect for society, committed and supportive citizenship, etc. \\
& Multiculturalism: cultural diversity, multicultural society, intercultural understanding, etc. \\
& Peace: culture of peace, peaceful, human security, etc. \\
& Health: health promotion, factors that determine healthy levels of life, etc. \\
& ICTs: access to ICTs, digital gap, etc. \\
\hline
\end{tabular}

Biodiversity: biological diversity

Climate change: climate-based problems

Conservation of the natural environment: conservation of environmental resources

Eco-design: eco-labelling and eco-product

Ecology: industrial ecology, organic livestock, organic production, organic farming, etc.

Environmental Energy: energy efficiency, use of renewable energies, conservation of energy resources, etc.

Waste management: minimisation of waste, waste management, etc.

Environmental impact: environmental impact, environmental repercussions, environmental implications, etc.

Environmental engineering: environmental engineering

Environmental legislation: environmental regulations, environmental standards, etc.

Environmental problems: environmental problems, etc.

Environmental protection: environmental commitment, sensitivity towards environmental issues, respect for the environment, etc.

Recycling: recycled paper, waste recycling, etc.

Natural resources: conserve the earth's resources, reduced and efficient use of natural resources, etc.

Rural development

Environmental technology

Sustainable urban development: sustainable urban planning, urban sustainability, eco-urbanism, etc.

Market economy: harmonising market needs with environmental protection and the objective of social equity

Environmental management: economic repercussions of environmental management

Economic

Poverty: reduction of poverty

Responsible consumption and production: social and environmental effects of consumption habits

Corporate social responsibility: corporate social responsibility and social responsibility

\section{References}

1. Bautista-Puig, N.; Casado, E.S. Sustainability practices in Spanish higher education institutions: An overview of status and implementation. J. Clean. Prod. 2021, 126320. [CrossRef]

2. Alghamdi, N.; Den Heijer, A.; De Jonge, H. Assessment tools' indicators for sustainability in universities: An analytical overview. Int. J. Sustain. High. Educ. 2017, 18, 84-115. [CrossRef]

3. Holm, T.; Sammalisto, K.; Grindsted, T.S.; Vuorisalo, T. Process framework for identifying sustainability aspects in university curricula and integrating education for sustainable development. J. Clean. Prod. 2015, 106, 164-174. [CrossRef]

4. Lozano, R.; Ceulemans, K.; Alonso-Almeida, M.; Huisingh, D.; Lozano, F.J.; Waas, T.; Lambrechts, W.; Lukman, R.; Hugé, J. A review of commitment and implementation of sustainable development in higher education: Results from a worldwide survey. $J$. Clean. Prod. 2015, 108, 1-18. [CrossRef] 
5. Grindsted, T.; Holm, T. Thematic development of declarations on sustainability in higher education. Environ. Econ. 2012, 1, 32-39. [CrossRef]

6. Grindsted, T. Sustainable universities-from declarations on sustainability in higher education to national law. Environ. Econ. 2011, 2, 29-36. [CrossRef]

7. Scott, W.; Gough, S. Universities and sustainable development: The necessity for barriers to change. Perspectives 2007, 11, 107-115. [CrossRef]

8. Wright, T. The evolution of sustainability declarations in higher education. In Higher Education and the Challenge of Sustainability; Springer: Dordrecht, The Netherlands, 2004; pp. 7-19.

9. Shriberg, M. Institutional assessment tools for sustainability in higher education: Strengths, weaknesses, and implications for practice and theory. High. Educ. Policy 2002, 15, 153-167. [CrossRef]

10. Major, L.; Namestovski, Z.; Horák, R.; Bagány, A.; Pintér, V. Teach it to sustain it! Environmental attitudes of Hungarian teacher training students in Serbia. J. Clean. Prod. 2017, 154, 255-268. [CrossRef]

11. Nagata, Y. A critical review of Education for Sustainable Development (ESD) in Japan: Beyond the practice of pouring new wine into old bottles. Educ. Stud. Jpn. 2017, 11, 29-41. [CrossRef]

12. Leihy, P.; Salazar, J. Education for Sustainability in University Curricula: Policies and Practice in Victoria. Melbourne: Centre for the Study of Higher Education, University of Melbourne. Prepared for Sustainability Victoria. Available online: https: / / bit.ly/3bB5kEe (accessed on 26 June 2013).

13. Nomura, K.; Abe, O. Higher education for sustainable development in Japan: Policy and progress. Int. J. Sustain. High. Educ. 2010, 11, 120-129. [CrossRef]

14. Cotton, D.R.E.; Bailey, I.; Warren, M.F.; Bissel, S. Revolution and second-best solutions: Education for sustainable development in higher education. Stud. High. Educ. 2009, 34, 719-733. [CrossRef]

15. Sterling, S.; Scott, W. Higher education and ESD in England: A critical commentary on recent initiatives. Environ. Educ. Res. 2008, 14, 386-398. [CrossRef]

16. Fan, R.J.D.; Tan, P.J.B. Application of information technology in preschool aesthetic teaching from the perspective of sustainable management. Sustainability 2019, 11, 2179. [CrossRef]

17. Abd-Elwahed, M.S.; Al-Bahi, A.M. Sustainability awareness in engineering curriculum through a proposed teaching and assessment framework. Int. J. Technol. Des. Educ. 2021, 31, 633-651. [CrossRef]

18. Alexa, L.; Maier, V.; Șerban, A.; Craciunescu, R. Engineers changing the world: Education for sustainability in Romanian Technical Universities-An empirical web-based content analysis. Sustainability 2020, 12, 1983. [CrossRef]

19. Pujol, F.A.; Tomás, D. Introducing Sustainability in a Robotic Engineering Degree: A Case Study. Sustainability 2020, $12,5574$. [CrossRef]

20. Sonetti, G.; Barioglio, C.; Campobenedetto, D. Education for Sustainability in Practice: A Review of Current Strategies within Italian Universities. Sustainability 2020, 12, 5246. [CrossRef]

21. United Nations. World Summit on Sustainable Development. Johannesburg, 26 August-4 September 2002. Available online: https:/ / bit.ly/38kRbIZ (accessed on 15 March 2015).

22. United Nations. Rio Declaration on Environment and Development. Río de Janeiro. Available online: https://www.un.org/ spanish/esa/sustdev/documents/declaracionrio.htm (accessed on 15 March 2015).

23. United Nations. The Future We Want Río de Janeiro. Brazil, 20-22 June 2012. Available online: https:/ / bit.ly/31KYpUn (accessed on 15 March 2015).

24. Perrault, E.K.; Albert, C.A. Utilizing project-based learning to increase sustainability attitudes among students. Appl. Envirom. Educ. Commun. 2017, 17, 96-105. [CrossRef]

25. Kieu, T.K.; Singer, J.; Gannon, T.J. Education for sustainable development in Vietnam: Lessons learned from teacher education. Int. J. Sustain. High. Educ. 2016, 17, 853-874. [CrossRef]

26. Cebrián, G.; Junyent, M. Competencies in education for sustainable development: Exploring the student teachers' views. Sustainability 2015, 7, 2768-2786. [CrossRef]

27. Christie, B.A.; Miller, K.K.; Cooke, R.; White, J.G. Environmental sustainability in higher education: What do academics think? Environ. Educ. Res. 2015, 21, 655-686. [CrossRef]

28. Watson, M.K.; Lozano, R.; Noyes, C.; Rodgers, M. Assessing curricula contribution to sustainability more holistically: Experiences from the integration of curricula assessment and students 'perceptions at the Georgia Institute of Technology. J. Clean. Prod. 2013, 61, 106-116. [CrossRef]

29. Barth, M.; Rieckmann, M. Academic staff development as a catalyst for curriculum change towards education for sustainable development: An output perspective. J. Clean. Prod. 2012, 26, 28-36. [CrossRef]

30. Sánchez-Carracedo, F.; Moreno-Pino, F.M.; Romero-Portillo, D.; Sureda, B. Education for sustainable development in Spanish university education degrees. Sustainability 2021, 13, 1467. [CrossRef]

31. Miñano Rubio, R.; Uribe, D.; Moreno-Romero, A.; Yáñez, S. Embedding sustainability competences into engineering education. The case of informatics engineering and industrial engineering degree programs at Spanish universities. Sustainability 2019, 11, 5832. [CrossRef] 
32. Valderrama-Hernández, R.; Alcántara Rubio, L.A.; Sánchez-Carracedo, F.; Caballero, D.; Serrate, S.; Gil-Domènech, D.; VidalRaméntol, S.; Miñano, R. ¿Forma en sostenibilidad el sistema universitario español? Visión del alumnado de cuatro universidades. Educ. XX1 2019, 23, 221-245. [CrossRef]

33. Bautista-Cerro Ruiz, M.J.; Díaz González, M.J. La sostenibilidad en los grados universitarios: Presencia y coherencia. Teoría Educ. 2017, 29, 161-187. [CrossRef]

34. Azcárate Goded, P.; González-Aragón, C.; Guerrero-Bey, A.; Cardeñoso Domingo, J.M. Análisis de la presencia de la sostenibilidad en los planes de estudios de los grados: Un instrumento para su análisis. Educar 2016, 52, 263-284. [CrossRef]

35. Qablan, A.; Al-Qaderi, S. How to Change University Faculty Members' Attitudes and Behavior in the Context of Education for Sustainable Development. Appl. Environ. Educ. Commun. 2009, 8, 184-194. [CrossRef]

36. Cortese, A.D.; Hattan, A.S. Education for sustainability as the mission of higher education. Sustain. J. Rec. 2010, 3, 48-52. [CrossRef]

37. Sterling, S.; Thomas, I. Education for sustainability: The role of capabilities in guiding university curricula. Int. J. Innov. Sustain. Dev. 2006, 1, 349-370. [CrossRef]

38. Kalsoom, Q.; Khanam, A. Inquiry into sustainability issues by preservice teachers: A pedagogy to enhance sustainability consciousness. J. Clean. Prod. 2017, 164, 1301-1311. [CrossRef]

39. Christie, B.A.; Miller, K.K.; Cooke, R.; White, J.G. Environmental sustainability in higher education: How do academics teach. Environ. Educ. Res. 2013, 19, 385-414. [CrossRef]

40. Romero, S.; Aláez, M.; Amo, D.; Fonseca, D. Systematic Review of How Engineering Schools around the World Are Deploying the 2030 Agenda. Sustainability 2020, 12, 5035. [CrossRef]

41. Sánchez-Carracedo, F.; Ruiz-Morales, J.; Valderrama-Hernández, R.; Muñoz-Rodríguez, J.M.; Gomera, A. Analysis of the presence of sustainability in Higher Education Degrees of the Spanish university system. Stud. High. Educ. 2019, 1-18. [CrossRef]

42. Sánchez-Carracedo, F.; Moreno-Pino, F.M.; Sureda, B.; Antúnez, M.; Gutiérrez, I. A methodology to analyze the presence of sustainability in engineering curricula. Case of study: Ten Spanish engineering degree curricula. Sustainability 2019, $11,4553$. [CrossRef]

43. Miotto, G.; Blanco-González, A.; Díez-Martín, F. Top business schools legitimacy quest through the Sustainable Development Goals. Heliyon 2020, 6, 1-11. [CrossRef]

44. Khan, T. Sustainability accounting courses, Talloires Declaration and academic research. Int. J. Sustain. High. Educ. 2013, 14, 42-55. [CrossRef]

45. Wu, Y.C.J.; Huang, S.; Kuo, L.; Wu, W.H. Management education for sustainability: A web-based content analysis. Acad. manag. Learn. Educ. 2010, 9, 520-531. [CrossRef]

46. Corrêa, M.; De Medeiros Lima, B.V.; Martins, V.W.B.; Rampasso, I.S.; Anholon, R.; Quelhas, O.L.; Leal Filho, W. An analysis of the insertion of sustainability elements in undergraduate design courses offered by Brazilian higher education institutions: An exploratory study. J. Clean. Prod. 2020, 272, 122733. [CrossRef]

47. Teruel-Serrano, M.D.; Vinals, M.J. Teaching environmental sustainability and responsibility in the Anthropocene: Overview of Tourism Studies in Spain. J. Teach. Travel. Tour. 2020, 20, 216-231. [CrossRef]

48. Miñano, R. Estudio de la Integración de la Sostenibilidad en Grados de Ingeniería Industrial. In Proceedings of the En Actas del IV Congreso Internacional de Ciencias de la Educación y el Desarrollo, Santiago de Compostela, Spain, 23-25 June 2016; pp. 29-34. Available online: http:/ / oa.upm.es/48775/ (accessed on 20 December 2016).

49. Arefin, M.A.; Nabi, M.N.; Sadeque, S.; Gudimetla, P. Incorporating sustainability in engineering curriculum: A study of the Australian universities. Int. J. Sustain. High. Educ. 2021, 22, 576-598. [CrossRef]

50. Fisher, J.; Bonn, I. Sustainability and Undergraduate Management Curricula: Changes Over a 5-year period. Aust. J. Environ. Educ. 2017, 33, 18-33. [CrossRef]

51. Colombo, C.R.; Alves, A.C. Sustainability in engineering programs in a Portuguese Public University. Production 2017, 27, 1-16. [CrossRef]

52. Nicolaou, I.; Conlon, E. What do final year engineering students know about sustainable development? Eur. J. Eng. Educ. 2012, 37, 267-277. [CrossRef]

53. Azapagizc, A.; Perdan, S.; Shallcross, D. How much do engineering students know about sustainable development? The findings of an international survey and possible implications for the engineering curriculum. Eur. J. Eng. Educ. 2005, 30, 1-19. [CrossRef]

54. Olaskoaga-Larrauri, J.; González-Laskibar, X.; Barrenetxea-Ayesta, M.; Díaz-De-Basurto-Uraga, P. The sign of the new millennium. Organisational changes and job satisfaction at Spanish public universities. Eur. J. Educ. 2019, 54, 137-150. [CrossRef]

55. ANECA 2015. Support Guide for the Preparation of the Verification Report for Official University Degrees. Available online: https: / / bit.ly/37Ys2Vp (accessed on 10 January 2020).

56. Zabalza, M.Á.; Cerdeiriña, M.A.Z. Planificación de la Docencia en la Universidad: Elaboración de Las Guías Docentes de Las Materias; Narcea SA de Ediciones: Madrid, Spain, 2012; ISBN 978-8427717299.

57. Aznar Minguet, P.; Ull Solís, M.A.; Martínez-Agut, M.P.; Piñero, A. El Tesauro de Sostenibilidad. Universidad de Valencia. Available online: https: / bit.ly/2XI0ujs (accessed on 15 December 2019).

58. United Nations Decade of Education for Sustainable Development (2005-2014): International Implementation Scheme. Available online: http:/ / unesdoc.unesco.org/images/0014/001486/148654so.pdf (accessed on 20 February 2016). 
59. Ull, M.A.; Aznar Minguet, P.; Martínez-Agut, M.P.; Piñero, A. Competencias para la sostenibilidad en los planes de estudio de los grados de ciencias de la Universitat de València. Enseñanza Las Cienc. Rev. Investig. Exp. Didácticas 2013, 3406-3411. Available online: https://raco.cat/index.php/Ensenanza/article/view/308439/398454 (accessed on 1 July 2021).

60. Olsson, D.; Gericke, N.; Chang Rundgren, S.N. The effect of implementation of education for sustainable development in Swedish compulsory schools-assessing pupils' sustainability consciousness. Environ. Educ. Res. 2016, 22, 176-202. [CrossRef]

61. Borg, C.; Gericke, N.; Höglund, H.O.; Bergman, E. Subject-and experience- bound differences in teachers' conceptual understanding of sustainable development. Environ. Educ. Res. 2014, 20, 526-551. [CrossRef]

62. Aerts, W.; Cormier, D.; Magnan, M. Corporate environmental disclosure, financial markets and the media: An international perspective. Ecol. Econ. 2008, 64, 643-659. [CrossRef]

63. ROYAL DECREE 1393/2007, OF OCTOBER 29, which Establishes the Organization of Official University Education. Available online: http:/ / www.boe.es/boe/dias/2007/10/30/pdfs / A44037-44048.pdf (accessed on 25 January 2009).

64. Birnbaum, R. The cybernetic institution: Toward an integration of governance theories. High. Educ. 1989, 18, 239-253. [CrossRef]

65. Weick, K.E. Educational Organizations as Loosely Coupled Systems. Adm. Sci. Q. 1976, 21, 1-19. [CrossRef]

66. Olaskoaga-Larrauri, J.; Guerenabarrena-Cortazar, L.; Cilleruelo-Carrasco, E. Academic staff attitudes and barriers to integrating sustainability in the curriculum at Spanish universities. Cult. Educ. 2021, 33, 373-396. [CrossRef]

67. Guerenabarrena-Cortazar, L.; Olaskoaga-Larrauri, J.; Cilleruelo-Carrasco, E. Obstáculos a la sostenibilización curricular en la universidad española. Arch. Analíticos Políticas Educ. 2021, 29, 1-20. [CrossRef] 